\title{
Repression by Methionine of Cystathionase Formation in Escherichia coli
}

\author{
By R. J. ROWBURY AND D. D. WOODS \\ Microbiology Unit, Department of Biochemistry, University of Oxford
}

(Received 8 November 1963)

\begin{abstract}
SUMMARY
Cystathionase catalyses the formation of homocysteine from cystathionine; its formation in cultures of Escherichia coli is repressed by the presence of methionine in the growth medium, and to a similar extent to that shown with homocysteine methylase (the enzyme complex which catalyses the conversion homocysteine $\rightarrow$ methionine). Cystathionase, again like homocysteine methylase, is formed rapidly without concomitant growth when repressed organisms are transferred to a medium free from methionine; such enzyme formation is prevented by chloramphenicol, suggesting that de novo synthesis of protein is required. The co-repression by methionine of the two enzyme systems fortifies the evidence that cystathionase is a component of the normal pathway of methionine synthesis by $E$. coli and consequently that its substrate, cystathionine, is a normal intermediate. Cystathionase preparations also formed pyruvate from cysteine; this activity paralleled that of cystathionase itself when the methionine status of the medium was changed, and it is concluded that the same protein is responsible for both activities.
\end{abstract}

\section{INTRODUCTION}

In previous work in this laboratory Wijesundera \& Woods (1962) showed that L-cystathionine was converted to homocysteine, pyruvate and ammonia by a cystathionase enzyme present in several strains of Escherichia coli. Since homocysteine is undoubtedly the immediate precursor of methionine in this organism (see review by Guest \& Woods, 1962), these observations supported the view, originating from the properties of methionine auxotrophs of $E$. coli and other micro-organisms, that cystathionine is an earlier intermediate, though there remained some evidence to the contrary (see Discussion). The final reaction by which homocysteine is converted to methionine is a complicated one requiring folic acid derivatives and, in certain circumstances, also cobalamin as cofactors (Guest \& Woods, 1962). However, the formation of the enzyme complex (homocysteine methylase), and indeed individual components of it, is repressed by the presence of methionine in the culture medium; the enzymes are, however, rapidly resynthesized when methionine is removed (Rowbury \& Woods, 1961; Foster, Rowbury \& Woods, 1963). The main objective of the present work was to examine the effect of growth with methionine on the cystathionase content of $E$. coli with conditions under which it could be strictly compared with the known effect on the homocysteine methylase complex. 


\section{METHODS}

Organisms. The several auxotrophic strains of Escherichia coli used were maintained on slopes of tryptic digest of meat agar; stocks were subcultured monthly and stored at about $4^{\circ}$ after incubation for $18 \mathrm{hr}$ at $37^{\circ}$. Their growth requirements were: strain PA 15 (originally obtained from Dr Barbara Wright) serine or glycine; strain 121/176 (Davis \& Mingioli, 1950) methionine or cobalamin; strain 26/18 (obtained from Dr B. D. Davis) homocysteine or methionine.

Organisms for the preparation of washed suspensions or cell-free extracts were grown on the glucose + lactate medium $(G L)$ of Guest, Helleiner, Cross \& Woods (1960) supplemented with glycine (10 mM), DL-methionine (0.3 mM) and DL-homocysteine (mM) for strains PA 15, 121/176 and 26/18, respectively; media were autoclaved for $7 \mathrm{~min}$. at $115^{\circ}$. Growth was in conical flasks (11., containing 200$500 \mathrm{ml}$. medium) which were shaken in air for $16-18 \mathrm{hr}$ at $37^{\circ}$ with a circular motion of 220 rotations $/ \mathrm{min}$. and radius $2 \mathrm{~cm}$. The size of the inoculum was so adjusted that growth reached the equivalent of $0.4-0.7 \mathrm{mg}$. dry wt. organism $/ \mathrm{ml}$. The cultures were centrifuged at $2200 \mathrm{~g}$ for $15 \mathrm{~min}$. and the organisms washed once with the culture volume of water. Inocula were derived from cultures $(6 \mathrm{ml}$.) in the same medium seeded from an $18 \mathrm{hr}$ culture on tryptic meat agar and incubated in 1shaped tubes $\left(150 \times 150 \times 16 \mathrm{~mm}\right.$.) which were shaken for $8 \mathrm{hr}$ at $37^{\circ}$ at 36 oscillations/min. of excursion $10 \mathrm{~cm}$.

Cell-free extracts. Washed organisms were resuspended in water (equiv. 20-30 mg. dry wt./ml.) and subjected to ultrasonic vibration and further treatment as described by Guest et al. (1960); in some experiments the dialysed extract was also treated with Dowex-1 resin by the method of these authors. The protein content of the final preparation was determined spectrophotometrically according to Layne (1957).

Extract of heated Escherichia coli (strain PA 15) was prepared as by Guest et al. (1960); it was normally used at $0.1 \mathrm{ml} . / \mathrm{ml}$. of reaction mixture.

Cell-free extracts of certain other organisms used in one group of experiments only (Table 3) were made available by other workers in this laboratory.

Study of enzyme formation. Organisms in which enzyme formation had been repressed were obtained by growth in the presence of DL-methionine (10 mM) in medium $G L$ supplemented with any other growth factor required by the strain under test. After washing in the culture volume of water, the harvested organisms were suspended (equiv. $3 \mathrm{mg}$. dry wt. $/ \mathrm{ml}$.) in the same medium, but without methionine. The suspensions $\left(\mathbf{3 0 0 - 5 0 0 ~} \mathrm{ml}\right.$. in 1 l. conical flasks) were shaken at $37^{\circ}$ as described for the original growth of cultures. Samples were taken at intervals (usually $1 \mathrm{hr}$ ) for assessment of the extent of growth and for the preparation of cell-free extracts in which enzyme was determined.

Assay of cystathionase, serine hydratase (deaminase) and cysteine desulphhydrase (deaminase). Cell-free extract (equivalent to 1-5 mg. protein) was incubated at $37^{\circ}$ for $30 \mathrm{~min}$. in $2 \mathrm{ml}$. volumes of solution $B$ which contained (in $133 \mathrm{~mm}$ phosphate buffer, $\mathrm{pH} \mathrm{7 \cdot 4):} \mathrm{MgSO}_{4}, 0.25 \mathrm{~mm}$; pyridoxal phosphate, $0.25 \mathrm{~mm}$; L-cystathionine, $10 \mathrm{~mm}$ (or DL-allocystathionine, $20 \mathrm{~mm}$ ). The cystathionine was replaced, when required, by $\mathrm{D}$ - or $\mathrm{L}$-serine $(10 \mathrm{mM})$ or by $\mathrm{L}$-cysteine $(10 \mathrm{mM})$. The reaction was stopped (and proteins precipitated) by addition of trichloroacetic acid $(0.5 \mathrm{ml}$; 
$25 \%, w / v)$. The supernatant fluid after centrifugation was used for the estimation of pyruvate by the method of Friedemann \& Haugen (1943), as modified by Wijesundera \& Woods (1962).

Methionine synthesis by cell-free extracts. This assay was based on the experiments of Guest et al. (1960) and was done by the procedure described by Rowbury \& Woods (1961). When required DL-homocysteine $(5 \mathrm{mM})$ was replaced as substrate by L-cystathionine ( $5 \mathrm{~mm}$ ) or DL-allocystathionine (10 $\mathrm{mm})$.

Detection and assay of homocysteine. The microbiological method described by Wijesundera \& Woods (1962) with Escherichia coli strain 26/18 (which responds to homocysteine and methionine) was used, as was the chromatographic procedure used by those authors.

Chemicals. The L-cystathionine used was the batch described by Wijesundera \& Woods (1962) isolated from the mycelium of a mutant of Neurospora crassa. DLAllocystathionine was obtained from the California Corporation for Biochemical Research (Los Angeles, U.S.A.). Other special chemicals were as described by Guest et al. (1960).

\section{RESULTS}

\section{Cystathionase activity of various strains of Escherichia coli}

Earlier experiments in this laboratory on the cystathionase of Escherichia coli (Wijesundera \& Woods, 1962) were made with a pyridoxin auxotroph (B 166) and a wild strain (F); furthermore the cell-free extracts then used were prepared by shaking with minute glass balls. It was first necessary to establish that the strain (PA 15) chosen for the present work contained the enzyme, and that it survived ultrasonic treatment of the organisms. Cell-free extracts of strain PA 15 prepared in this way produced both a keto acid and homocysteine from L-cystathionine; the

Table 1. The effect of pyridoxal phosphate and magnesium ions on cystathionase activity

Ultrasonic extract (Escherichia coli PA 15) was dialysed for $18 \mathrm{hr}$ and one sample treated with Dowex-1 resin. Cystathionase activity was tested in solution $B$ with the stated omissions. Incubation was for $\mathbf{3 0} \mathrm{min}$.

\begin{tabular}{|c|c|c|}
\hline & $\begin{array}{r}\text { Cystathio } \\
\text { ( } \mu \text { mole pyruva } \\
\text { with }\end{array}$ & $\begin{array}{l}\text { e activity } \\
\text { ng. protein/hr) } \\
\text { tract }\end{array}$ \\
\hline Omission & Dialysed only & $\begin{array}{l}\text { Dialysed and } \\
\text { treated with } \\
\text { Dowex-1 }\end{array}$ \\
\hline None & $0 \cdot 66$ & 0.71 \\
\hline $\mathrm{MgSO}_{4}$ & $0 \cdot 70$ & 0.63 \\
\hline Pyridoxal phosphate & $0 \cdot 27$ & 0.08 \\
\hline
\end{tabular}

keto acid was identified as pyruvic acid by the absorption spectrum of its 2,4dinitrophenyl hydrazone, and the homocysteine both by paper chromatography and by the growth response of $E$. coli strain 26/18. Formation of pyruvate was used thereafter for the routine assay of cystathionase activity in ultrasonically prepared extracts. Pyruvate increased linearly with time up $60 \mathrm{~min}$. and was maximal at a cystathionine concentration of $8 \mathrm{~mm}$; the conditions chosen for normal tests were $10 \mathrm{~mm}$-cystathionine and an incubation period of $30 \mathrm{~min}$. 
Cystathionase activity of dialysed extracts was increased about twofold by pyridoxal phosphate; a considerable increase in resolution of the enzyme was obtained by treatment with Dowex-1 resin (Table 1). Contrary to the results of Wijesundera \& Woods (1962) the omission of $\mathbf{M g}^{2+}$ had little effect with either the crude or dialysed enzyme preparations (Table 1 ).

Table 2. Effect of homocysteine and methionine on the activity of cystathionase

Cystathionase activity of an extract of Escherichia coli PA 15 was assayed in solution $B$ with the stated additions. Ineubation was for $30 \mathrm{~min}$.

\begin{tabular}{|c|c|c|c|}
\hline Addition & $\begin{array}{c}\text { Conen. } \\
\text { (mM) }\end{array}$ & $\begin{array}{c}\text { Cystathionase } \\
\text { activity } \\
\text { ( } \mu \text { mole pyruvate } / \mathrm{mg} . \\
\text { protein } / \mathrm{hr})\end{array}$ & $\begin{array}{c}\text { Inhibition } \\
(\%)\end{array}$ \\
\hline None & - & 1.94 & - \\
\hline DL-Methionine & $\begin{array}{r}1.0 \\
10 \cdot 0\end{array}$ & $\begin{array}{l}1.94 \\
1.96\end{array}$ & $\begin{array}{l}0 \\
0\end{array}$ \\
\hline DL-Homocysteine & $\begin{array}{r}0.1 \\
1.0 \\
10 \cdot 0\end{array}$ & $\begin{array}{l}1 \cdot 84 \\
1 \cdot 28 \\
0 \cdot 16\end{array}$ & $\begin{array}{r}5 \\
85 \\
92\end{array}$ \\
\hline
\end{tabular}

Table 3. Cystathionase activity of various strains of Escherichia coli and of other organisms

The strains of Escherichia coli and Salmonella typhimurium were grown on basal medium $G L$ and harvested at a similar stage of growth.

$\begin{array}{lc}\text { Organism } & \begin{array}{c}\text { Cystathionase activity } \\ \text { ( } \begin{array}{c}\text { mole pyruvate } / \mathrm{mg} . \\ \text { protein/hr) }\end{array}\end{array} \\ \text { E. coli } \mathbf{P A} 15 & 1 \cdot 05 \\ \mathbf{3} / 62 & 1 \cdot 05 \\ 121 / 176 & 0 \cdot 93 \\ 113 / 3 & 0 \cdot 76 \\ 26 / 18 & 0 \cdot 00 \\ \text { Rhodopseudomonas spheroides } & 0 \cdot 57 \\ \text { Acetobacter rancens } & 0 \cdot 84 \\ \text { Micrococcus denitrificans } & 0 \cdot 77 \\ \text { Salmonella typhimurium } & 0 \cdot 68 \\ \text { Pseudomonas AM1 } & 0 \cdot 03 \\ \text { Penicillium Q176 } & 0 \cdot 03\end{array}$

The breakdown of cystathionine was not affected by the presence of equimolar concentration of DL-methionine, but was inhibited $(90 \%)$ by a similar concentration of DL-homocysteine and perceptibly by even one-hundredth of this (Table 2). Wijesundera \& Woods (1962) also reported marked inhibition by homocysteine (and also by cysteine and glutathione). It was concluded that the cystathionase enzyme present in Escherichia coli strain PA 15 was essentially similar to that studied previously in other strains.

Distribution. The enzyme was absent from ultrasonic extracts of Escherichia coli strain 26/18 (Table 3), thus confirming the results obtained by Wijesundera \& Woods (1962) who used a different method of disintegration. This strain 26/18 grows with either homocysteine or methionine, but not with cystathionine; a metabolic lesion in the conversion cystathionine $\rightarrow$ homocysteine was therefore expected. The enzyme was present in three other strains of $\boldsymbol{E}$. coli, and in four other organisms, in activity 
comparable to that of $\boldsymbol{E}$. coli PA 15; with two organisms however (neither of which required methionine for growth) only slight activity was found with the type of preparation tested.

Conversion of cystathionine to methionine. In later work it was desired to compare the effect of growth of the organism in the presence of methionine on the conversion of: (a) cystathionine to homocysteine, $(b)$ homocysteine to methionine, $(c)$ cystathionine to methionine. It was first necessary to establish that $(c)$ occurred by the successive action of the enzymes which catalysed $(a)$ and $(b)$; a direct reductive fission of cystathionine to methionine and glycine was a theoretical possibility, although Wijesundera (1954) found no evidence for this with intact organisms.

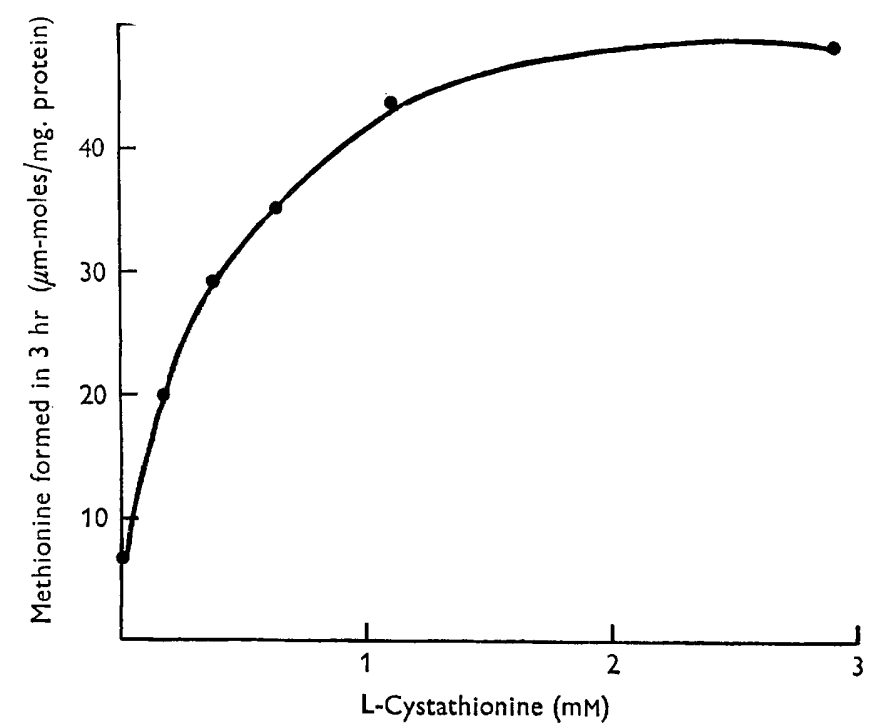

Fig. 1. The effect of the concentration of cystathionine on its conversion to methionine by cell-free extracts of Escherichia coli PA 15.

Table 4. Conversion of cystathionine to methionine

Cell-free extracts of the stated strains of Escherichia coli were used. The concentration of DL-allocystathionine was $10 \mathrm{~mm}$; other substrates, 5 mM. Incubation was for $3 \mathrm{hr}$.

$\quad \begin{gathered}\text { Strain of } \\ \text { E. } \text { coli }\end{gathered}$
PA 15

$26 / 18$
$121 / 176$
$121 / 176+\mathbf{2 6} / 18$

Substrate
L-Cystathionine
DL-Allocystathionine
DL-Homocysteine
L-Cystathionine
-Cystathionine
-Cystathionine

L-Methionine formed -mole/mg. protein in $3 \mathrm{hr}$ )

Methionine was formed by ultrasonic extracts from cystathionine (and allocystathionine) at about half the rate at which it was formed from homocysteine (Table 4). Synthesis increased linearly with time up to about $4 \mathrm{hr}$, and with increasing cystathionine concentration up to about $1.5 \mathrm{~mm}$ (Fig. 1); the $K_{m}$ was 
about $0.4 \mathrm{~mm}$. At the lowest concentration of cystathionine tested $(0.2 \mathrm{~mm})$ there was about $30 \%$ conversion to methionine.

Serine was required for significant synthesis of methionine from cystathionine (Table 5), as it is also for synthesis from homocysteine (Guest et al. 1960). Furthermore, a source of the folic acid cofactor system (either extract of heated organisms or tetrahydropteroylglutamate + cobalamin) was essential (Table 5). Tetrahydropteroylglutamate (in the absence of cobalamin) strongly inhibited the action of the extract of heated Escherichia coli. These properties are the same as those described for the conversion of homocysteine to methionine by ultrasonic extracts of the same strain (Guest et al. 1960) and would not be expected if cystathionine were cleaved directly to methionine and glycine.

Table 5. Cofactor requirements for the conversion of cystathionine to methionine

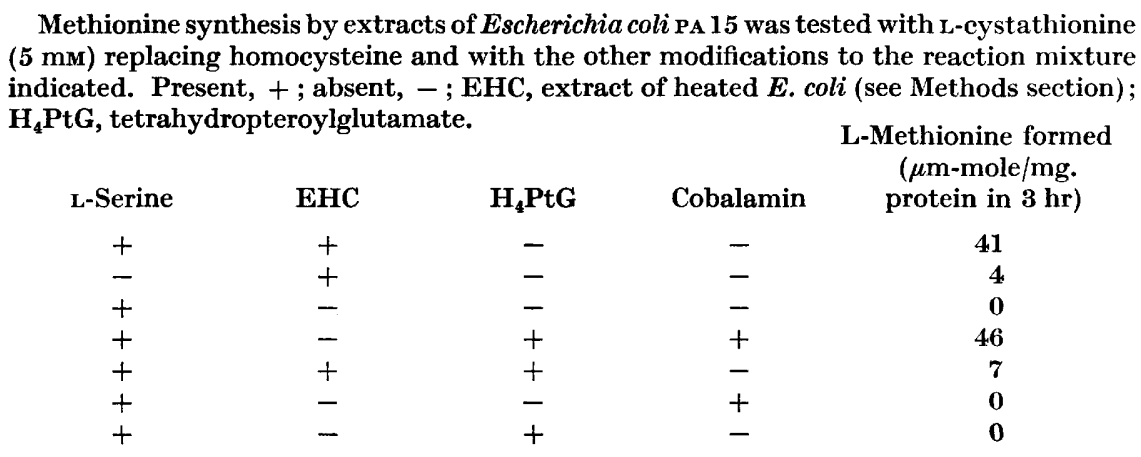

It has been shown (Table 3) that extracts of Escherichia coli 26/18 lack cystathionase whilst it was known that extracts of strain 121/176 lack homocysteine methylase activity (i.e. ability to convert homocysteine to methionine) unless cobalamin is present (Guest et al. 1960; Foster, Tejerina \& Woods, 1961). Neither extract alone converted cystathionine to methionine, but a mixture of the two was effective ('Table 4), thus confirming the view that methionine formation from cystathionine requires the successive action of cystathionase and homocysteine methylase, and that in this particular case each organism provides the enzyme or enzymes lacking in the other.

\section{Repression of the formation of cystathionase}

Although it had already been established that growth in the presence of methionine represses the formation of homocysteine methylase by Escherichia coli PA 15 (Rowbury \& Woods, 1961), further experiments with this enzyme system were included in the present series with cystathionase so that a strict quantitative comparison might be made. Ultrasonic extracts derived from organisms grown with DLmethionine (10 mM) had only about $20 \%$ of the cystathionase activity of preparations from organisms grown without methionine. Loss of activity increased with increasing concentration of methionine in the growth medium; the sharpest decrease occurred between 0.1 and $1.0 \mathrm{~mm}$, a range over which the effect on homocysteine methylase production was also greatest (Table 6). The degree of repression of enzyme formation at all methionine concentrations was however slightly greater with homocysteine methylase than with cystathionase (Table 6). The overall synthesis of 
methionine from cystathionine by ultrasonic extracts of organisms grown with methionine was also greatly decreased compared with the controls, and to an extent similar to that of the decrease in homocysteine methylase activity (Table 7).

Following the terminology of Wijesundera \& Woods (1960) organisms and derived enzyme preparations obtained after growth in the presence and absence of methionine will be referred to as ' inactive' and 'active', respectively, the former term now indicating a severely restricted content of both cystathionase and homocysteine methylase.

\title{
Table 6. Effect of methionine on the formation of cystathionase
}

The figures in parentheses indicate the percentage decrease in activity due to the presence of methionine during growth. Enzyme assays were on extracts of Escherichia coli PA 15 grown with the stated concentration of methionine.

\begin{tabular}{|c|c|c|}
\hline $\begin{array}{l}\text { DL-Methionine } \\
\text { in growth } \\
\text { medium (mM) }\end{array}$ & $\begin{array}{c}\text { Homocysteine methylase } \\
\text { ( } \mu \mathrm{m} \text {-mole methionine/mg. } \\
\text { protein } / \mathrm{hr})\end{array}$ & $\begin{array}{l}\text { Cystathionas } \\
(\mu \text { mole pyruva } \\
\text { mg. protein } / 1\end{array}$ \\
\hline 0 & 60 & $1 \cdot 8$ \\
\hline 0.001 & $58(4)$ & $1 \cdot 6(10)$ \\
\hline 0.01 & $50(16)$ & $1.5(17)$ \\
\hline $0 \cdot 1$ & 39 (35) & $1.4(22)$ \\
\hline 1 & $11(81)$ & $0.6(67)$ \\
\hline 10 & $8(86)$ & $0.4(78)$ \\
\hline
\end{tabular}

Table 7. Effect of growth with methionine on the conversion of cystathionine to methionine

\begin{abstract}
The figures in parentheses indicate the percentage decrease in methionine formed due to the presence of methionine in the growth medium. Extracts of Escherichia coli PA 15 harvested after growth with the stated concentration of methionine were used.
\end{abstract}

DL-Methionine
in growth
medium $(\mathrm{mm})$
0
$0 \cdot 001$
$0 \cdot 01$
$0 \cdot 1$
1
10

L-Methionine formed ( $\mu \mathrm{m}$-mole/mg. protein in $3 \mathrm{hr}$ ) from

\begin{tabular}{cc}
\hline Homocysteine & Cystathionine \\
83 & 52 \\
$75(10)$ & $42(19)$ \\
$71(15)$ & $36(31)$ \\
$67(19)$ & $30(42)$ \\
$21(75)$ & $15(71)$ \\
$18(78)$ & $10(81)$
\end{tabular}

When 'active' organisms were transferred to a medium containing methionine and incubated, the cystathionase activity of ultrasonic extracts decreased exactly in proportion to the extent of growth. It appears that, as in the case of homocysteine methylase (Rowbury \& Woods, 1961), there is no destruction of cystathionase and that it is simply 'diluted out' by new organisms containing only limited amounts of the enzyme.

Effect of homocysteine. Methionine is the ultimate product of the metabolic pathway in which cystathionase presumably functions and it represses the formation of this enzyme. Homocysteine is the immediate product and has been shown above to inhibit the activity of the enzyme; it has however only a small effect on the formation of the enzyme. The presence of DL-homocysteine (10 mM) during growth resulted only in a $20 \%$ decrease in cystathionase activity, an effect which given was by DL-methionine at one-hundreth of the concentration (Table 6). 
Relief from repression. When 'inactive' organisms were transferred to a methionine-free medium their cystathionase content (as judged by the activity of ultrasonic extracts) increased rapidly for $3 \mathrm{hr}$ (Fig. 2); the major part of this increase occurred during the first $2 \mathrm{hr}$, a period during which there was no significant growth. The rate of increase was similar to that of homocysteine methylase, which was assayed in the same cell-free preparations. As expected, the organism also

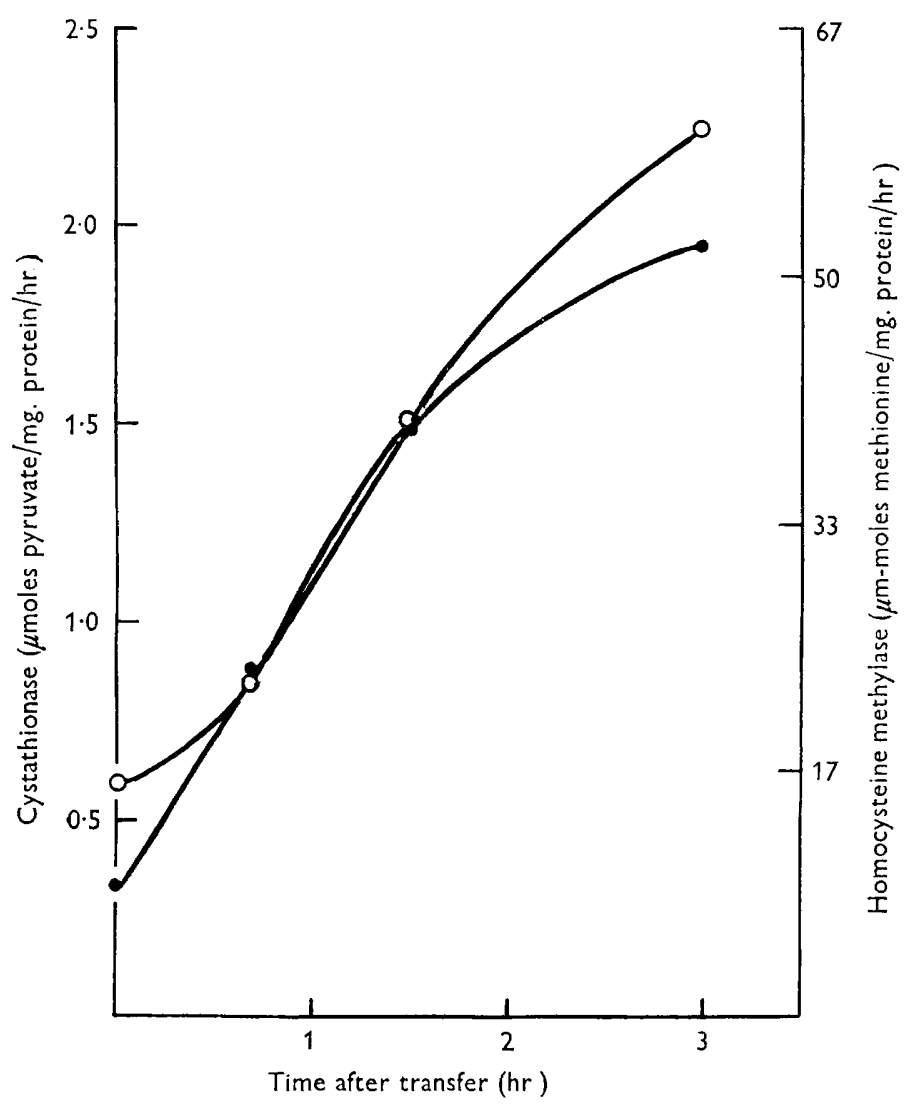

Fig. 2. Appearance of cystathionase $(O)$ and homocysteine methylase (O) activity in Escherichia coli PA 15 following transfer from a methionine-rich to a methionine-free medium. Enzyme activity determined in cell-free extracts of organisms harvested at the stated time.

regained the ability to bring about the over-all conversion (in the presence of serine) of cystathionine to methionine (Fig. 3); the relative rate of synthesis of methionine from cystathionine and homocysteine remained constant during the recovery period.

The increase in cystathionase (and homocysteine methylase) activity on transfer of 'inactive' organisms to methionine-free medium did not occur when chloramphenicol was added (Fig. 4). Since the main increase takes place in advance of growth this effect cannot be a secondary one due to inhibition of growth and provides evidence that relief from repression requires synthesis of new protein; further evidence for this in the case of homocysteine methylase was given by Rowbury $\&$ Woods (1961). 


\section{Specificity of cystathionase}

Allocystathionine. This stereoisomer of the substrate was tested (DL-form) arbitrarily at twice the optimal concentration of L-cystathionine and was degraded at about the same rate (Table 8). The individual isomers of DL-allocystathionine were

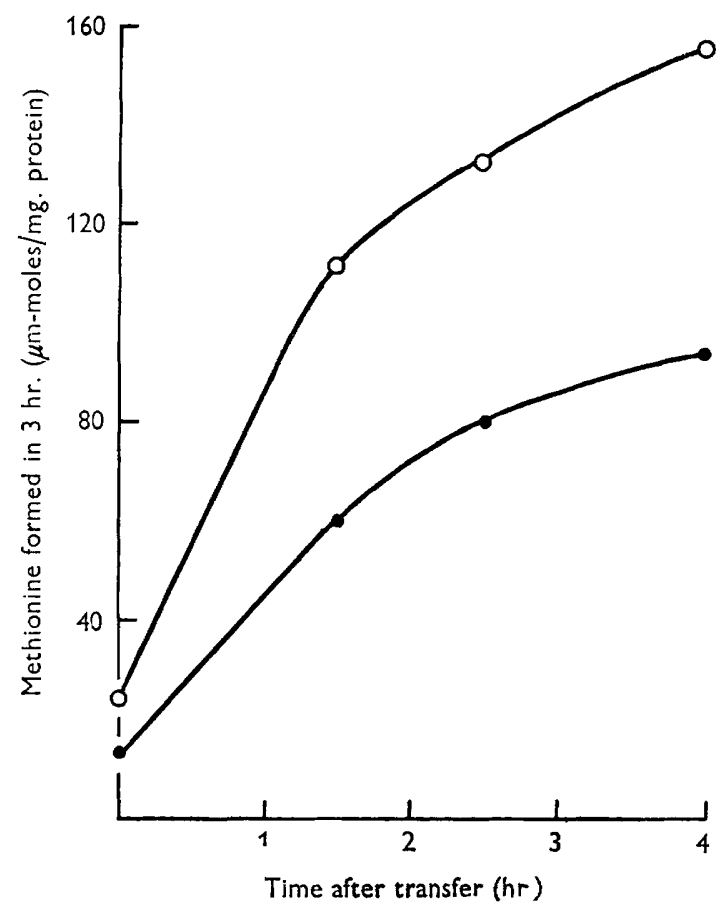

Fig. 3. Relative activity of Escherichia coli PA 15 in converting homocysteine $(O)$ and cystathionine (๑) to methionine following transfer from a methionine-rich to a methioninefree medium. Activity determined in cell-free extracts of organisms harvested at the stated time.

Table 8. Pyruvate production from certain amino acids by extracts of Escherichia coli

All substrates except DL-allocystathionine (20 $\mathrm{mm}$ ) were present at a final concentration of $10 \mathrm{~mm}$.

\section{Strain of \\ E. coli}

PA 15

26/18
Substrate

L-Cystathionine
DL-Allocystathionine
D-Serine
L-Serine
DL-Serine
L-Cysteine
DL-Homocysteine
L-Cystathionine
L-Cysteine
L-Serine
D-Serine

Pyruvate formed ( $\mu$ mole/mg. protein/hr)

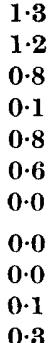


not available for testing, but, unless the enzyme preparations contained a homocysteine racemase, it is certain that $\mathrm{D}$-allocystathionine (which contains a $\mathrm{L}$ homocysteine residue) is the isomer attacked since L-methionine is formed by the further action of homocysteine methylase (Table 4). It cannot, however, be con-

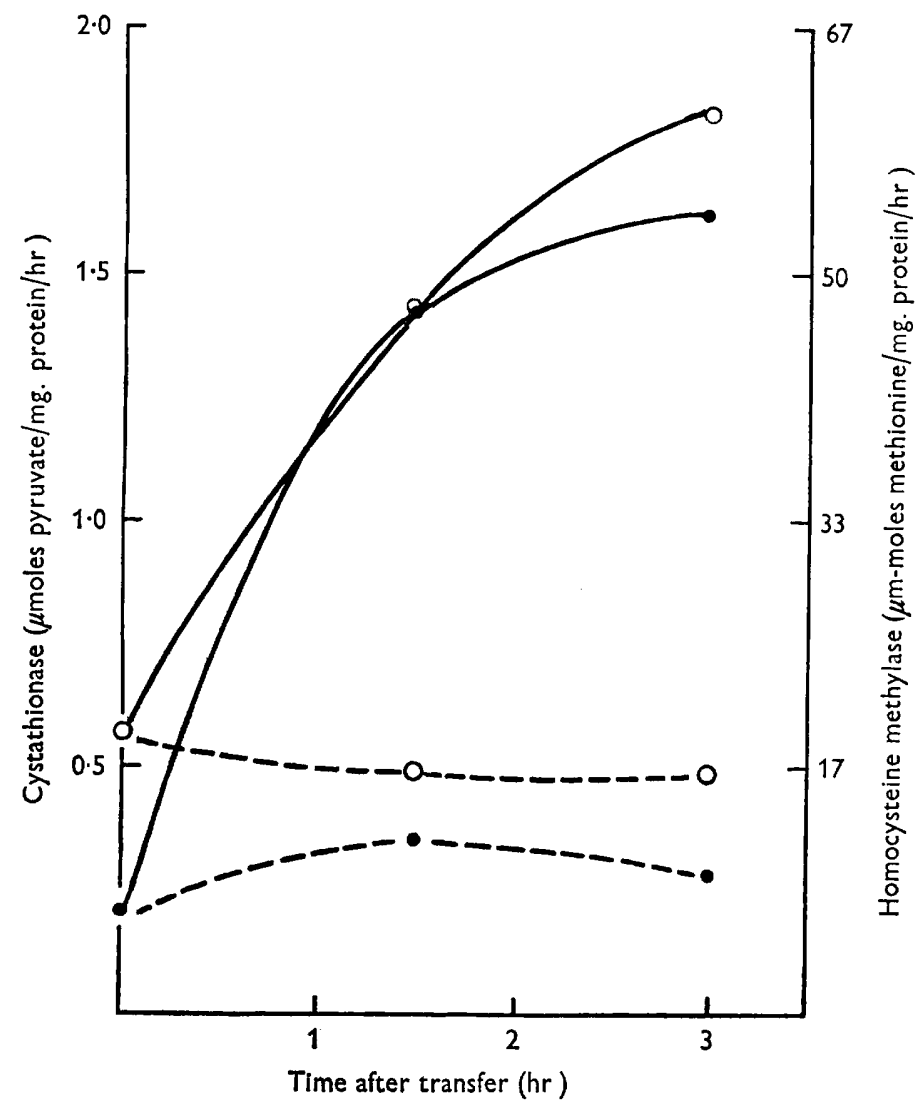

Fig. 4. Formation of cystathionase $(O)$ and homocysteine methylase $(O)$ in the presence $(--)$ and absence $(-)$ of chloramphenicol (0.125 mM). Activity determined in cellfree extracts prepared at intervals after transferring the organisms from methionine-rich to methionine-free medium.

Table 9. Effect of methionine on the formation of D-serine dehydratase (deaminase) and L-cysteine desulphhydrase (deaminase)

Extracts of Escherichia coli PA 15 harvested after growth with the stated concentration of methionine were used for the enzyme assay.

\begin{tabular}{ccc}
$\begin{array}{c}\text { DL-Methionine } \\
\text { in growth }\end{array}$ medium (mM) & $\begin{array}{c}\text { Pyruvate formed } \\
(\mu \mathrm{mole} / \mathrm{mg} \text {. protein/hr }) \text { from }\end{array}$ \\
\cline { 2 - 3 } 0 & D-Serine & L-Cysteine \\
$0 \cdot 001$ & $0 \cdot 64$ & $0 \cdot 31$ \\
$0 \cdot 01$ & $0 \cdot 73$ & $0 \cdot 28$ \\
$0 \cdot 1$ & $0 \cdot 72$ & $0 \cdot 24$ \\
1 & $0 \cdot 68$ & $0 \cdot 18$ \\
10 & $0 \cdot 59$ & $0 \cdot 05$ \\
& $0 \cdot 59$ & $0 \cdot 03$
\end{tabular}


cluded that L-allocystathionine (containing a D-homocysteine residue) is not attacked since any $\mathrm{D}$-methionine formed would not have been detected by the microbiological assay used. DL-Allocystathionine, which, unlike cystathionine, was available commercially, was used in some later experiments.

Cysteine. Crude cell-free extracts formed pyruvate from L-cysteine at about a half the rate from L-cystathionine (Table 8 ). No attempt was made by purification procedures to determine whether cysteine deaminase activity was due to a distinct enzyme or was a function of the cystathionase enzyme itself. Instead, techniques suggested by the preceding work were used.

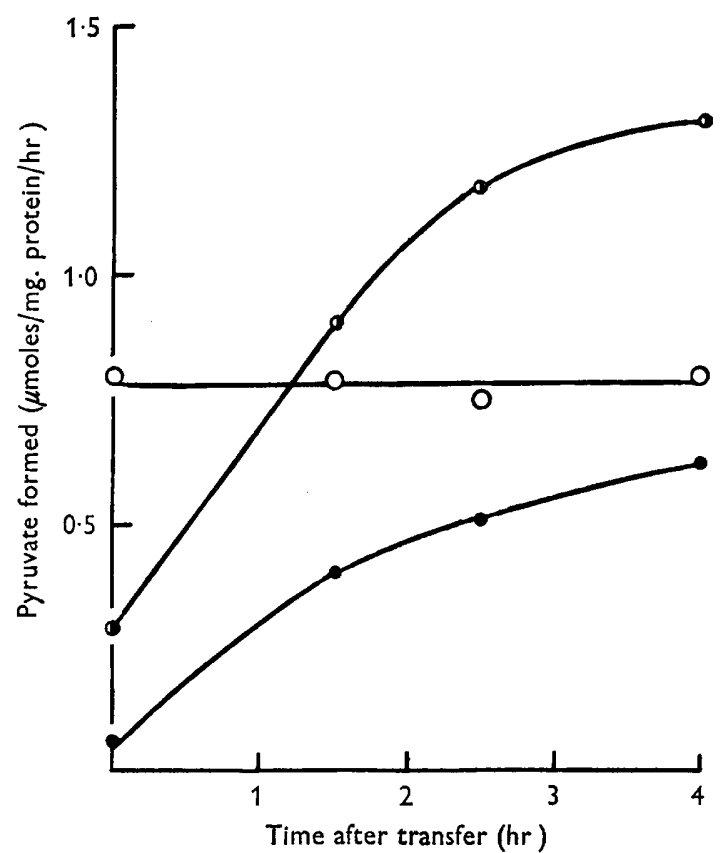

Fig. 5. Changes in the activity of the L-cysteine desulphhydrase ( $\bullet$ ), D-serine dehydratase (O) and cystathionase (O) of Esherichia coli PA 15 following transfer from methionine-rich to methionine-free medium. Activity, assessed in each case in terms of pyruvate formed, was determined in cell-free extracts of organisms harvested after the time stated.

Ability to metabolize L-cysteine was decreased to $10 \%$ by growth of the organism in the presence of methionine; as with cystathionase the sharpest fall of activity occurred in the range 0.1-1.0 mM-methionine (Table 9). Furthermore, reappearance of cystathionase on transfer of the organisms to methionine-free medium was accompanied by reappearance of cysteine desulphhydrase activity (Fig. 5). Escherichia; coli strain 26/18, which lacks cystathionase, also lacks cysteine desulphhydrase (Table 8 ) it is unlikely that a single mutation would affect the production of two proteins. Finally the degradation of cysteine by cell-free preparations of strain PA 15 was inhibited $90 \%$ by DL-homocysteine (10 mM) as was also the case with cystathionine as substrate (Table 2). It is concluded provisionally that cystathionine and cysteine are attacked by the same enzyme.

Serine. Crude cell-free extracts of Escherichia coli PA 15 formed pyruvate from 
D-serine (though not from $\mathrm{L}$-serine) at two-thirds the rate from cystathionine (Table 8). In this case, however, it is clear from investigations analogous to those used with cysteine that a different enzyme catalyses the reaction. Activity was not significantly decreased by growth in the presence of methionine (Table 9), nor did it increase in parallel with increase of cystathionase (Fig. 5). The strain of $E$. coli (26/18) deficient in cystathionase contained an active D-serine deaminase (Table 8 ).

\section{DISCUSSION}

The growth response of methionine auxotrophs of Escherichia coli to possible precursors suggests strongly that cysteine is converted to methionine, as in Neurospora, through the successive intermediate formation of cystathionine and homocysteine (Lampen, Roepke \& Jones, 1947; Gots \& Koh, 1950; Horowitz, 1947). Cystathionine is, however, contra-indicated as an intermediate in $E$. coli by the work of Bolton, Cowie \& Sands (1952), who showed that the addition of unlabelled cystathionine to cultures growing with $\left[{ }^{35} \mathrm{~S}\right]$ sulphate as sole source of sulphur did not, as would be expected, decrease the incorporation of ${ }^{35} \mathrm{~S}$ into methionine. Wijesundera \& Woods (1962) established the presence in the organism of an enzyme which attacked cystathionine (cystathionase) and whose specific products were homocysteine, pyruvate and ammonia; the case for cystathionine as an intermediate was thus strengthened since active enzymic mechanisms (homocysteine methylase) for the further conversion of homocysteine to methionine had been described (see review by Guest \& Woods, 1962).

Furthermore, in the present work cell-free extracts of the test strain of Escherichia coli catalysed the over-all formation of methionine from cystathionine under conditions, discussed in Results, which make it clear that homocysteine is an intermediate. With intact organisms of the same strain, Wijesundera (1954) found only slight conversion of cystathionine to methionine ( $10 \%$ of the rate with homocysteine); it is possible that the intact organism has limited permeability to exogenous cystathionine, a possibility which might also explain the results (quoted above) of Bolton et al. (1952).

The phenomenon of enzyme repression (in the terminology of Vogel, 1957) provides an interesting and novel approach to the determination of the status of a possible intermediate in a biosynthetic pathway. In several cases the ultimate product is known to repress the formation of enzymes which catalyse a number of steps in the reaction sequence, though not always to the same extent. Examples of this are the biosynthesis of arginine and pyrimidine by Escherichia coli and of histidine by Salmonella typhimurium (Gorini \& Maas, 1958; Yates \& Pardee, 195\%; Ames \& Garry, 1959). One of the earliest described cases of enzyme repression was that of homocysteine methylase, the enzyme complex catalysing the last step of methionine synthesis by $E$. coli; the initial observations of Wijesundera \& Woods (1953) and Cohn, Cohen \& Monod (1953) were amplified by Wijesundera \& Woods (1960) while Rowbury \& Woods (1961) showed that relief from repression entailed synthesis of new protein. The present results establish that formation of cystathionase, as well as of homocysteine methylase, is repressed by methionine. It seems reasonble to take this as a priori evidence that cystathionase (and therefore cystathionine) is a functional entity in methionine biosynthesis, especially since cystathionase 
formation is not markedly repressed by its own immediate product (homocysteine). It is difficult to envisage any explanation other than a control mechanism for this specific effect of methionine. The slight repression caused by homocysteine (at high concentrations) is probably due to methionine formed from it by the growing organism. It may be noted that homocysteine does exhibit the second type of feedback control shown by products, that is, inhibition of the activity of the enzyme.

The extent of repression of cystathionase (and the rate of new enzyme formation on relief from repression) was quantitatively similar to that with homocysteine methylase. Recent studies in this laboratory, reported briefly by Rowbury (1962), show that enzymes which catalyse the synthesis of cystathionine are also repressed, and to a similar degree, by methionine. It is possible therefore that control of methionine synthesis is another example of the 'co-ordinate repression' shown to occur in the histidine pathway by Ames \& Garry (1959).

Application of the principles of enzymic repression also permits a novel approach to obtaining evidence, without purifying an enzyme preparation, as to whether two distinct chemical events are or are not manifestations of the activity of the same enzyme. In the present case cysteine desulphydrase (deaminase) activity disappeared and reappeared in parallel with that of cystathionase; this and other evidence led to the conclusion that both activities are a function of the same protein. On the other hand, $\mathbf{D}$-serine dehydratase (deaminase) activity was not affected when cystathionine was repressed or resynthesized; this supports the conclusion of Wijesundera \& Woods (1962), based on purification and selective inactivation, that the enzymes which attack D-serine and cystathionine are distinct entities.

One of us (R. J. R.) is indebted to the Agricultural Research Council for a Studentship. The work was aided by grants to the Department from the United States Department of Health, Education and Welfare.

\section{REFERENCES}

Ames, B. N. \& Garry, B. (1959). Co-ordinate repression of the synthesis of four histidine biosynthetic enzymes by histidine. Proc. nat. Acad. Sci., Wash. 45, 1453.

Bolton, E. T., Cowie, D. B. \& Sands, M. K. (1952). Sulfur metabolism in Escherichia coli. III. The metabolic fate of sulfate sulfur. J. Bact. 63, 309.

Cohn, M., Cohen, G. M. \& Monod, J. (1953). L'effet inhibiteur spécifique de la méthionine dans la formation de la méthionine-synthase chez Escherichia coli. C.R. Acad. Sci., Paris, 236, 746.

Davis, B. D. \& Mingioli, F. S. (1950). Mutants of Escherichia coli requiring methionine or vitamin $\mathrm{B}_{12}$. J. Bact. 60, 17.

Foster, M. A., Rowbury, R. J. \& Woods, D. D. (1963). Control of the methylation of homocysteine in Escherichia coli. J. gen. Microbiol. 31, xix.

Foster, M. A., Tejerina, G. \& Woods, D. D. (1961). Two enzymic mechanisms for the methylation of homocysteine by Escherichia coli. Biochem. J. 81, I P.

Friedemann, T. E. \& Haugen, G. E. (1943). Pyruvic acid. II. The determination of keto acids in blood and urine. J. biol. Chem. 147, 415 .

Gorini, L. \& MAAS, W. K. (1958). Feedback control of the formation of biosynthetic enzymes. In The Chemical Basis of Development. Ed. by W. D. McElroy \& B. Glass, p. 469. Baltimore: Johns Hopkins Press.

Gots, J. S. \& Кон, W. Y. (1950). Methionine synthesis in Escherichia coli. Bact. Proc. p. 134.

Guest, J. R., Helleiner, C. W., Cross, M. J. \& Woons, D. D. (1960). Cobalamin and the synthesis of methionine by ultrasonic extracts of Escherichia coli. Biochem. J. 76, 396. 
Guest, J. R. \& Woods, D. D. (1962). Metabolic interrelationships between cobalamin and folic acid in the synthesis of methionine by Escherichia coli. 2 Europäisches Symposion über Vitamin $\mathrm{B}_{12}$ und Intrinsic Factor. Ed. by H. C. Heinrich, p. 686. Stuttgart: Ferdinand Enke Verlag.

Horowitz, N. H. (1947). Methionine synthesis in Neurospora. The isolation of cystathionine. J. biol. Chem. 171, 255.

Lampen, J. O., Roepke, R. R. \& Jones, M. J. (1947). Studies on the sulfur metabolism of Escherichia coli. III. Mutant strains of Escherichia coli unable to utilize sulfate for their complete sulfur requirements. Arch. Biochem. 13, 55.

LAYNE, E. (1957). Spectrophotometric and turbidimetric methods for measuring proteins. In Methods in Enzymology. Ed. by S. P. Colowick \& N. O. Kaplan, vol. 3, p. 451. New Academic Press.

RowBURy, R.J. (1962). Control of cystathionine formation in Escherichia coli by methionine. Biochem. J. 82, 24 P.

Rowbury, R. J. \& Woods, D. D. (1961). Further studies on the repression of methionine synthesis in Escherichia coli. J. gen. Microbiol. 24, 129.

Vogel, H. J. (1957). Repression and induction as control mechanisms of enzyme biogenesis : the 'adaptive' formation of acetylornithinase. In The Chemical Basis of Heredity. Ed. by W. D. McElroy \& B. Glass, p. 276. Baltimore: Johns Hopkins Press.

Widesundera, S. (1954). Methionine and Related Compounds in Compounds in the Metabolism of Micro-organisms. D.Phil. Thesis, University of Oxford.

WiJesundera, S. \& Woods, D. D. (1953). The effect of growth on a medium containing methionine on the synthesis of this amino acid by Bacterium coli. Biochem. J. 55, viii.

WiJesundera, S. \& Woods, D. D. (1960). Suppression of methionine synthesis in Escherichia coli by growth in the presence of this amino acid. J. gen. Microbiol. 22, 229.

WiJesundera, S. \& Woods, D. D. (1962). The catabolism of cystathionine by Escherichia coli. J. gen. Microbiol. 29, 535.

Yates, R. A. \& PARdee, A. B. (1957). Control by uracil of formation of enzymes required for orotate synthesis. J. biol. Chem. 277, 677 . 